\title{
P85 - Asthmatic children and adolescents treated in daily medical practice - results from a 2-year sublingual allergen immunotherapy (AIT) study with grass pollen tablets
}

\author{
Efstrathios Karagiannis ${ }^{1 *}$, Kija Shah-Hosseini ${ }^{2}$, Meike Hadler ${ }^{1}$, Ralph Mösges ${ }^{2}$ \\ From 3rd Pediatric Allergy and Asthma Meeting (PAAM) \\ Athens, Greece. 17-19 October 2013
}

\section{Background}

The aim of this non-interventional study was to document the impact of a sublingual allergen immunotherapy (AIT) with Oralair 5-grass pollen tablets (Stallergenes, France) on symptom severity (rhinitis, conjunctivitis, asthma), use of symptomatic medication and tolerability in patients with grass pollen-induced allergic rhinoconjunctivitis (RC) over 2 years of routine medical practice treatment. This poster focuses on the subgroup of asthmatic children (4-11 yrs) and adolescents (12-17 yrs).

\section{Methods}

This prospective, open, non-controlled, non-interventional, multicenter study was conducted from September 2010 to October 2012 in Germany. Overall 1.482 patients (93 asthmatic children (6.2\%), 73 asthmatic adolescents (4.9\%)) participated in the study.

The patients rated their symptoms as a combined score of severity (scale: 0 [none] -3 [severe]) and frequency (scale: 0 [none] -4 [very often]). In the combined RC score, the severity of rhinitis and conjunctivitis were pooled (scale: 0 [none] - 6 [severe]). In the asthma score, the severity and the frequency were pooled (scale: 0 [none] -7 [severe]).

\section{Results}

During the season preceding AIT treatment 93/ 92\% of children/ adolescents with asthma had used symptomatic medication for RC symptoms. This rate dropped to $64 / 68 \%\left(1^{\text {st }}\right.$ season $)$ and to $57 / 41 \%\left(2^{\text {nd }}\right.$ season). Likewise the RC score in these patients decreased from $4.06 / 4.13$ to $1.86 / 1.82$ ( $1^{\text {st }}$ year $)$ and to $1.33 / 1.59\left(2^{\text {nd }}\right.$ year). Also the asthma score was reduced from 3.36/ 3.55 to $1.24 / 1.51$ ( $1^{\text {st }}$ year) to $0.71 / 1.13$ ( $2^{\text {nd }}$ year $)$.

An improvement in health status after two years of treatment was documented by $96 / 96 \%$.

Adverse events occurred in 19.4/ $17.8 \%$ over two years of treatment. The incidence of non-fatal serious adverse events was $3.2 / 0.0 \%$.

At the end of the $2^{\text {nd }}$ season, $96 / 96 \%$ evaluated the tolerability of the 5 -grass pollen tablets as very good or good.

\section{Conclusion}

Based on the study results, AIT with Oralair 5-grass pollen tablets was well tolerated by children and adolescents with asthma in routine medical practice. Symptomatic medication for RC symptoms use was significantly reduced. The asthma- and the RC score were also reduced significantly after one and two years under treatment with Oralair 5 -grass pollen tablets compared to the season preceding AIT.

\section{Authors' details}

'Stallergenes GmbH, Kamp-Lintfort, Germany. ${ }^{2}$ Institute of Medical Statistics, Informatics and Epidemiology (IMSIE), University Hospital Cologne, Cologne, Germany.

${ }^{1}$ Stallergenes GmbH, Kamp-Lintfort, Germany

Full list of author information is available at the end of the article 

sublingual allergen immunotherapy (AIT) study with grass pollen tablets. Clinical and Translational Allergy 2014 4(Suppl 1):P140.

Submit your next manuscript to BioMed Central and take full advantage of:

- Convenient online submission

- Thorough peer review

- No space constraints or color figure charges

- Immediate publication on acceptance

- Inclusion in PubMed, CAS, Scopus and Google Scholar

- Research which is freely available for redistribution

Submit your manuscript at www.biomedcentral.com/submit
C Biomed Central 